\title{
Effects of Substituting Some Components of Broilers' Feed with Crude Aquous Extract of Fresh Leaves of
}

\section{Mucuna Poggei}

\author{
A. O. Oko (Correspondence author) \\ Department of Biotechnology, Ebonyi State University \\ P.M.B. 053 Abakaliki, Ebonyi State, Nigeria \\ Tel: 234-803-261-3614Ｅ-mail: austineok@yahoo.co.uk
}

S. T. Nwoba

Department of Biotechnology, Ebonyi State University

P.M.B. 053 Abakaliki, Ebonyi State, Nigeria

\author{
J. N. Idenyi
}

Department of Biotechnology, Ebonyi State University

P.M.B. 053 Abakaliki, Ebonyi State, Nigeria

O. Ogah

Department of Biotechnology, Ebonyi State University

P.M.B. 053 Abakaliki, Ebonyi State, Nigeria

O. O. Ugwu, \& L. U. Ehihia

Department of Biochemistry, Ebonyi State University

P.M.B. 053 Abakaliki, Ebonyi State, Nigeria

Received: June 14, 2012 Accepted: June 28, 2012

doi:10.5296/jbls.v3i1.xxx URL: http://dx.doi.org/10.5296/jbls.v3i1.xxx 


\section{Abstract}

We studied the effects of substitution of Palm kernel cake (PKC), Fishmeal and Soyabean Cake (SBC) with crude extract of Mucuna poggei on the performances of broilers. A total of forty broiler chicks of a day old each were bought and shared into four groups of ten broilers each, allowed to acclimatize for two weeks and then reared for eight weeks. Palm kernel Cake (PKC), Fishmeal and Soyabean Cake (SBC) were given to broilers in groups 1, 2 and 3 respectively with similar quantities of crude extract of Mucuna poggei fresh leaves. The fourth group served as a control and was fed normal feed (Fishmeal and Soyabean Cake). The weekly body weights of the broilers were taken for eight weeks, after which they were slaughtered for the determination of their carcass characteristics, breast meats' drip loss and cook loss. The results showed significant differences $(\mathrm{P}<0.05)$ in the weights of the broilers at the end of the experiment. The "control" had the highest mean body weight of $1233.33 \pm 76.38 \mathrm{~g}$ followed by "group 2" with mean body weight of $1150.00 \pm 50.00 \mathrm{~g}$ while "group 3" had the least mean body weight of $950 \pm 40.82 \mathrm{~g}$ followed by "group 1 " with mean body weight of $1000.00 \pm 40.82 \mathrm{~g}$. There was no significant variation $(\mathrm{P}<0.05)$ in the cooking losses among the breast meats of the four groups. However, the results showed significant variation $(\mathrm{P}<0.05)$ in the drip losses among the breast meats of the broilers. On the whole, the results revealed that the control which had no crude extract of Mucuna poggei fresh leaves performed better than other groups which were given the extract as feed substitute. The crude extract should therefore be given to broilers as feed supplement not as feed substitute for optimal performance.

Keywords: Palm kernel cake, Fishmeal, Soyabean cake, Broilers, Mucuna poggei, Carcass, Drip and Cook loss

\section{Introduction}

Poultry is a category of birds reared in homes for the purpose of provision of proteins to humans. The demand for poultry products have been increasing over the years. The poultry industry over the years has grown into a large commercial venture providing means of livelihood and employment for both skilled and unskilled workers (Esonu, 1996). The industry provides poultry birds either as source of meat (broilers) or as egg producers (layers), these serve as source of proteins for many people around the world. Poultry accounts for about $30 \%$ of meat production worldwide (Rallof and Janet, 2003). Broilers are the meat types of poultry. They usually have high feed conversion efficiency and are bred specifically for marketing at early age. They are usually sold when they attain the live weight of $1500 \mathrm{~g}$, which occurs between 4-8 weeks of age depending on their production efficiency (Egbo et al., 2000).

However, in Nigeria the major factor militating against poultry production in general and broilers in particular is the high cost of feeds. Feed cost constitutes the highest proportion of the capital required in running poultry farms. In developing countries including Nigeria, cost of feeds constitute as much as $70-80 \%$ of the total cost of poultry production as against $50-70 \%$ in most developed countries (Olomu, 1979). This is further compounded by scarcity of feed ingredients, inadequate knowledge of cheap ingredients, dearth of 
information on the use of agro-industrial by-products, over dependence on the importation of certain items like cereals and root crops (Olomu, 1979). Hence, it is necessary to resort to incorporation of local agro-by-products such as wheat offals, rice husks, groundnut cake, palm kernel cake, maize chaffs in poultry feeds, since they do not qualify for direct human consumption. There is need to also substitute some of these feed components due to their increasing scarcity with natural crops such as legumes.

Interestingly, there are a number of underutilized legumes such as the African yam beans (Shenostylis stenoscarpa), Mucuna conchinchinesis, Mucuna pruriens, Mucuna flagellipes Mucuna poggei etc. For instance, Mucuna poggei is increasingly becoming popular and much has been said about its nutritional and medicinal potentials. In most villages in Eastern Nigeria predominantly occupied by the "Igbos", Mucuna species such as Mucuna flagellipes and poggei leaves are squeezed in water and taken orally to boost blood levels (Ihedioha and Okoye, 2011). A study of the proximate and mineral composition of Mucuna poggei seeds reveals that it has about $3.58 \%$ crude fiber, $89.7 \%$ dry matter, $3.9 \%$ ash, $27.9 \%$ crude protein, $45.8 \% \%$ Nitrogen free extract andgreen energy of $4.13 \mathrm{Kcal} / \mathrm{g}$ (Tuleun et al., 2008). The high mineral content of the leaves such as Calcium, Magnessium, Potassium, Iron, Phosphorous, Zinc, Sodium etc is also interesting.

A critical assessment of the nutritional potentials of Mucuna poggei in the livestock industry has become very imperative. It is in this premise that we assessed the possibility of substituting this legume (Mucuna poggei) with some components of the broiler feeds by determining the effects of substituting palm kernel cake, fishmeal and soya bean cake with crude extracts of Mucuna poggei on the growth performances, carcass characteristics and meat quality of broilers.

\section{Materials and Method}

Preparation of crude extract of Mucuna poggei leaves: Fresh leaves of Mucuna poggei leaves were obtained from a local farm at the PRESCO Campus of Ebonyi State University, Abakaliki, Nigeria. The leaves were pounded and weighed using mortar and pestle and sensitive weighing balance respectively. About $50 \mathrm{~g}$ of the leaves were squeezed in $1000 \mathrm{ml}$ of water, mixed properly and filtered to obtain the crude extract. The crude extract were stored in bottles, covered and preserved in a refrigerator and then added to the water given to the broilers on daily basis.

Formulation of the broiler feeds: The feeds were formulated using conventional broiler feed formulas to meet the broilers' nutritional needs. The ratio used in the formulation of the feeds were soyabean cake $25 \%$, palm kernel cake $10 \%$, maize $50 \%$, rice offals $10 \%$, fishmeal $5 \%$, lysine $0.25 \%$, methionine $0.25 \%$ and salt $0.5 \%$. Soyabean cake and palm kernel cake were bought from Abakpa market in Abakaliki, Nigeria. Rice offals were obtained from Abakaliki rice Mill industry while fishmeal and maize were bought from dried fish and maize dealers. All the feed components were then milled and mixed together.

The amount of each component used for the feed formulation was determined thus:

Formula $=\% \mathrm{IR} \times \% \mathrm{DM} \times \mathrm{WNV} / 100$ 
Where $\mathrm{IR}=$ Incorporated rate in \%

$\mathrm{DM}=$ Dry matter content in $\%$

WNV=Wanted Nutritive value in \%

Experimental Layout: The experiment was carried out using forty broiler chicks of a day old each. The experimental birds were allowed to acclimatize, during which they were fed with commercial starter feeds bought in a market in Abakaliki, Nigeria and then shared into four groups of ten broilers each. Each group was put in a single cage. The "control" was fed with all the eight ingredients used in the feed formulation and the crude extract of Mucuna poggei was not included in its diets. The other three groups were fed as follows; "group 1" feed had palm kernel cake substituted with crude extract of Mucuna poggei, "group 2" feed had the fishmeal component substituted with Mucuna poggei leaves crude extract and soya bean cake was substituted with crude extract of Mucuna poggei in feed given to "group 3". The broilers were fed as described above for eight the weeks of the experiment.

Carcass Characteristics and Meat Quality Determination: At the end of the experiment, the birds were slaughtered for carcass characteristics and meat quality determination. The birds were fasted overnight and their weights obtained before slaughtering. They were bled and killed by cutting their jugular veins, scalded in warm water (about $60^{\circ} \mathrm{C}$ ) and the feathers were manually removed. The legs and heads were cut at tibio-metetarsus and atlanto-occiptal joints respectively. The weights of carcass, head, legs, hearts, livers and gizzards were obtained using a weighing balance. After which, carcasses were preserved in a refrigerator at $4^{0} \mathrm{C}$ for twenty four hours and then reweighed. And weight gains of the carcasses were obtained. Carcasses were then carved out and weights of breasts, thigh-drumsticks, wings, necks and back-cut were determined. The breast samples of the carcasses were used for drip loss determination. Meat samples of the breasts were placed in plastic bags and freely hanged up to a hook at $4^{0} \mathrm{C}$ during forty hours. The samples were then removed, mopped up and weighed for drip loss determination. Samples were placed in a hot water at $75^{\circ} \mathrm{C}$ during thirty minutes, cooled during forty minutes and then mopped. The differences in weights of the samples before and after cooking were used to determine the cook loss.

Statistical Analysis: All data obtained were analyzed by the Analysis of Variance (ANOVA) procedure using SAS software (SAS Institute, 1999). Differences were declared statistically significant at $\mathrm{P} \leq 0.05$. Where significant differences were detected, the means were separated by least significant difference (LSD) at $5 \%$ probability.

\section{Results}

Variation in Weekly Growth among the Broilers: The result of the weekly weight gained by the four groups of broilers used in the experiment is as shown in table 1. The mean weights of the broilers in the first week ranged from $280.00 \pm 32.59 \mathrm{~g}$ to $317.50 \pm 31.23 \mathrm{~g}$, the group 2 broilers had the highest mean weight of $317.50 \pm 31.23$ followed by group 1 with the mean weight of $310.00 \pm 28.50 \mathrm{~g}$. The group 3 broilers had the least mean weight of $280.00 \pm 32.59 \mathrm{~g}$ followed by the "Control" with the mean weight of $305.00 \pm 32.59 \mathrm{~g}$. There was an observable numerical increase in the weights of the broilers in the second week of the 
experiment, though there was no significant difference in the mean weights of the broilers $(\mathrm{P}>0.1781)$ and an average weight of $400.00 \mathrm{~g}$ was observed. However, there was a significant difference in the mean weights of the broilers during the third week $(\mathrm{P}<0.0014)$. The mean value of the means of the weights of the four groups of broilers was $530.00 \mathrm{~g}$; the mean weights for groups 1, 2, 3and control were $550.00 \pm 20.41 \mathrm{~g}, 550.00 \pm 25.00 \mathrm{~g}, 450.00 \pm 20.00 \mathrm{~g}$ and $575.00 \pm 54.01 \mathrm{~g}$ respectively. While there was significant variation among the mean weights of the broilers in the fourth week $(\mathrm{P}<0.0002)$, there was only numerical difference among the weights of the broilers in the four groups in both the fifth and sixth week of the experiment. Also table 1 show significant differences in the mean weights observed among the four groups in the seventh week of the experiment, suggesting variation bin the sizes of broilers in different groups. The mean weight of the broilers ranged from $812.50 \pm 32.00 \mathrm{~g}$ to $1116.67 \pm 104.08 \mathrm{~g}$. The broilers in the "Control" were the heaviest with the mean weight of $1116.67 \pm 104.08 \mathrm{~g}$ followed by group 2 with the mean weight of $1033.33 \pm 20.41 \mathrm{~g}$ while group 3 had the least mean weight of $812.50 \pm 32.00 \mathrm{~g}$ followed by group 1 with the mean weight of $900.00 \pm 20.41 \mathrm{~g}$. Similarly, during the eighth week, significant differences were observed among the mean weights of the broilers in the different groups $(\mathrm{P}<0.0001)$. The mean weight of the broilers for the eighth week was $1067.85 \mathrm{~g}$. The "control" had the highest mean weight of $1233.33 \pm 76.37 \mathrm{~g}$ followed by group 2 with the mean weight of $1150.00 \pm 50.00 \mathrm{~g}$. Group 3 had the least mean weight of $950.00 \pm 40.82$ followed by group 1 with the mean weight of $1000.00 \pm 40.82 \mathrm{~g}$.

Variation in the carcass sizes and weight lost of the broilers after slaughtering and removal of feathers: The table 2 below shows the mean weight of their carcass after removal of feathers and their net weight loss. The four groups of broilers showed significant differences $(\mathrm{P}<0.0015)$ in their weights before their feathers were plucked out. This indicates wide variation in the weights of the broilers used for the experiment. The $\mathrm{LSD}_{0.05}$ values show that no real differences existed between the weights of broilers in group $2(1200 \mathrm{~g})$ and the control (1233.33g). On the other hand, real difference existed between weight of broilers in group 2 and the control and that of groups 1 and 3. The initial mean weight of the broilers was $1104.167 \mathrm{~g}$, which ranged from $966.67 \mathrm{~g}$ to $1233.33 \mathrm{~g}$. However, significant differences $(\mathrm{P}<0.0009)$ existed among the weights of the carcasses after plucking out their feathers, suggesting a wide variation. The mean weight was $768.75 \mathrm{~g}$ and the values ranged from $833.33 \mathrm{~g}$ to $1091.67 \mathrm{~g}$. Group $3 \mathrm{had}$ the least mean weight $(833.33 \mathrm{~g})$ followed by group 1 (866.67g), while the control had the highest mean weight of $1091.67 \mathrm{~g}$ followed by group 2 with the mean weight of $1083.33 \mathrm{~g}$. Table 3 also shows the mean net weight of the broilers' carcasses after removal of their feathers and it showed no significant difference $(\mathrm{P}>0.3463)$. The mean net weight loss of the carcasses was $135.42 \mathrm{~g}$. The values ranged from $116.67 \mathrm{~g}$ to $150.00 \mathrm{~g}$ with group 1 having the highest value while group 2 had the least value.

Cook and drip losses of the broilers' breast meat sample: Table 4 shows the mean cook and mean drip loss of the breast meat of the broilers. The result showed no significant difference among the mean cooking losses of the breast meat of the four groups of broilers. The mean cook loss ranged from $46.67 \mathrm{~g}$ to $50.00 \mathrm{~g}$. The $\mathrm{LSD}_{0.05}$ reveals no statistical differences among the mean values of the cook loss of the broilers' breast meat. The table 
also shows that there is a significant difference $(\mathrm{P}<0.00115)$ in the drip loss of the broilers' breast meat. The drip losses of groups 1,2 and the "control" had no statistical difference as shown by the $\mathrm{LSD}_{0.05}$ in table 4 , while group 3 differed statistically. The mean drip loss ranged from $15 \mathrm{~g}$ to $25 \mathrm{~g}$. Group 3 had the least mean drip loss of $15 \mathrm{~g}$ while group 2 and "Control" had the highest mean drip loss of $25 \mathrm{~g}$ each followed by group 1 with mean drip loss of $20 \mathrm{~g}$.

\section{Discussion}

The observed variations in the weights of the broilers could be attributed to the nutritional content of the feeds given to the broilers in the individual groups. The "control" must have performed better than the other groups because its feeds were made up of all the major ingredients used in the feed formulation unlike the other groups where one of its feed ingredients was substituted with crude extract of Mucuna poggei leaves. A lot of workers have reported that fishmeal and soya bean cake contain high proteins necessary for the growth of animals and broilers inclusive, unlike $1.16 \%$ protein content of certain Mucuna species leaves as reported by Ihedioha and Okoye (2011), this is far lower than $20 \%$ protein content of certain Mucuna seeds reported by Enwere (1998).

Besides, certain anti-nutrient factors and toxic metals have been identified in Mucuna species by a lot of workers (Siddhuraju et al., 2000 and Delcarmen et al., 1996). They reported that Mucuna reduces feed palatability and digestibility of diets particularly proteins. Acamovie (2002) has reported that presence of tannin in Mucuna species reduces its palatability by binding with proteins. Similarly, Udensi et al., 2008, reported that seeds of non-heat treated Mucuna reduces the palatability of broiler feeds; this may also be true for its crude extract. The low palatability of crude extract of Mucuna poggei leaves to the broilers in groups 1, 2 and 3 and also its low protein content and presence of anti-nutrients could have caused the broilers in groups 1, 2 and 3 not to grow and gain as much weights as the broilers placed in the "control" which were not given the crude extract as feed substitute. The control maintained the highest mean weight through out the eight weeks of the experiment. This could due to the soyabean cake, fishmeal and palm kernel cake which were present in the feeds given to the broilers in the control, unlike other groups that had one of the three feed components substituted with crude extract of Mucuna poggei leaves. The growth performance and weight gained by broilers under the control explains the imparts of certain anti-nutrients contained in crude extract of Mucuna poggei leaves coupled with its low palatability as already reported. Lack of soya bean cake in the diets of group 3 broiler chicks might have contributed to their low average weight. This because heat treated soya bean cake contains up to $9 \%$ proteins and $80 \%$ calories responsible for the growth, weight gain and energy in animals including broilers as reported by the WHO in 1990. The low weight gain and growth of the group 3 broilers is therefore attributable to lower nutritional value of the crude extract of Mucuna poggei than in soya bean cake. Similarly, the absence of palm kernel cake and fish meal in the diets of group 1 broilers and group 2 broilers respectively may have affected their growth and weight, hence the "the control" performed more than the two groups due to the inclusion of the two ingredients in their diets. 
In the eighth week of the experiment, there was significant variation $(\mathrm{P}<0.0002)$ in the live weights of the broilers as shown by the analysis of variance. The mean live weights of the broilers in the "control" was $1233.3 \pm 76.37 \mathrm{~g}$ which was below the minimum marketable size of $1500 \mathrm{~g}$ and below the live weights of $1550 \mathrm{~g}$ reported by Narayangswamy and Santosh (2004) for six months old broilers. The broilers in the "control" were not as heavy as other broilers fed with crude extract of Mucuna poggei supplement and commercially blended feeds under the same conditions reported by other workers. It could be that there are other feed ingredients in those commercial feeds that were lacking in the formulated feeds used in this experiment. As a result improved nutrient content in the feeds might help to improve weight gain and growth rate of broilers fed with crude extract of Mucuna poggei leaves. Also, broilers fed with commercial feeds with out the extract appear to have higher feed conversion efficiency, growth rate and weight. This could be as result of absence of certain anti-nutrients in such feeds but contained in the crude extract of Mucuna poggei. Tuleun et al.(2008) reported the presence of $5.86 \%$ L-Dopa, $0.25 \%$ tannin, $0.22 \%$ phyate, $0.74 \%$ saponin, $0.03 \%$ oxalate, $2.3 \%$ alkaloids in seeds of Mucuna poggei seeds as well as high amount of HCN (13.14\%) and trypsin inhibitor (31.4\%). Phyate is an anti-nutrient known to increase mineral requirement in animals especially phosphorous, as it forms insoluble complexes with phytic acid. Prolonged intake of HCN even at low level as happens when the carrier is a staple food, results to damage to the central nervous system and the thyroid gland, which manifests as ataxia and goiter (Makkar and Becker, 1997 and Ekpechi, 1967). This level of certain phytochemicals in Mucuna poggei must have contributed to poor performance by the broilers it was fed with.

The carcasses of the broilers of the four groups showed significant variations before and after the removal of feathers from them as shown in table 2 , but no significant variation in the net loss of weight among the broilers existed after plucking out their feathers. The significant variations could be attributed to the wide differences in the sizes of the broilers of the different groups. The carcasses of broilers of the control weighed highest before and after plucking out their feathers (1233.33 \pm 76.37 and $1091.67 \pm 62.92$ respectively) followed by the carcass of the group 2 broilers which weighed $1200 \pm 50 \mathrm{~g}$ and $1083.33 \pm 57.74$ before and after the plucking out of their feathers respectively. The group 3 broilers had the least mean carcass weight followed by the group 1 broilers. The trend of the results indicated highest yield by the control followed by group 2, group 3 and then group 1, these could be attributed to their individual initial live weights. The broilers of groups 1, 2 and 3 had lower carcass weight. This result was similar with that of Dahouda et al (2003); Toleu and Igba (2008) and Ferrira et al (2003). They similarly reported lower carcass weight and dressing percentage of broilers fed with $20 \%$ raw Mucuna seed meal diets as a result of smaller live weight. In other words, carcass weight and size of broilers are dependent on their live weight. According to them, cut-parts of the chicks were improved when fed with processed seed of Mucuna.

The organ sizes of the broilers revealed that the broilers of the control had the highest weights for all the organs studied. The $\mathrm{LSD}_{0.05}$ showed that there was no real difference between the weights of the hearts of broilers in group 1, group 2 and the control but differed only with the weight of the hearts of broilers of group 3. These mean that the over all weight of the 
carcasses of the broilers did not have much effect on the size of the heads of the broilers. Similar observations were made for the sizes and weights of the broilers in all the groups. The $\mathrm{LSD}_{0.05}$ for the gizzard showed real differences among the four groups. Expectedly, the gizzard of broilers in the control had the highest mean weight of $30 \pm 2.0 \mathrm{~g}$, this supports the previous results which showed that the "control" were better than other groups in terms of overall size. The gizzard of broilers in group 3 had the least mean weight of $15 \pm 0 \mathrm{~g}$, which may be attributed to their carcass weight which were the least from other groups. Real differences between the sizes of legs and livers of broilers in the control and those of other groups were observed in the course of the study. These further indicate better performance of the broilers in the control than the ones in the other groups. This is in line with the previous report by Narayangswamy and Santosh (2004).

The drip loss and cook loss were used to determine the quality of the broilers. There were no significant variations $(\mathrm{P}>0.8592)$ in the cook losses of the breast meat of the broilers. The $\mathrm{LSD}_{0.05}$ also showed no real differences among the broilers in all the groups. This could be attributed to the proportion of the breast meat lost into the water and by implication, the result of the cook loss of the broilers means that the cooking qualities of the breast meat do not differ significantly. There was low proportion of meat lost into the water by the breast meat which agrees with the report of Allen, (2007) that low cook loss occur as a result of water holding capacity which prevents lost to water. There were significant variations in the drip loss of the broilers $(\mathrm{P}<0.0015)$. Group with higher cook loss had lower drip loss while group 3 with the lowest cook loss had the lowest drip loss. These indicate a correlation between the drip loss and the cook loss of the broilers' breast meat. The drip loss and cook loss of the broilers' breast meat were higher than the values obtained in local guinea fowl meat (Dahouda et al., 2009). Such differences might be due to factors such as rate and extent of $\mathrm{pH}$ decline, meat fat content, proteolysis and protein oxidation (Siddhuraju et al., 1996). Omojola and Adesehinwa, (2007) observed that the lower the cook loss of a meat the more juicy the meat. The low cook loss of the meat of broilers in groups 1,2 and 3 can be attributed to their juiciness and high quality.

\section{Conclusion}

The outcome of the study showed that the broiler chicks could not really perform optimally largely due to the composition of the feeds given to them. The formulated feeds used for the study which composed of basically Palm kernel cake, Fish meal, Rice offals, Soya bean cake and 50\% maize appeared not to be as nutritious as some commercially blended broiler feeds, as shown by the sizes and live weights of the broilers. We therefore suggest inclusion of other protein and calorie sources in locally prepared feeds and each of the feed ingredients should be included in adequate proportion to provide maximum nutrients for poultry animals and broilers in particular. There should be better processing of the crude extract of Mucuna poggei leaves and adequate research into the nutrients and anti-nutrients composition of the crude extract in order to ascertain its real potentials in serving as feed supplements or substitute not only in broilers but in other related livestock. It is expected that the findings of the experiment will go a long way in reducing the increasing problem of livestock feed scarcity and its attendant high price in the local market. 


\section{1) Macrothink}

Table 1. Variation in Weekly Weights (in grams) of the Broilers

\begin{tabular}{|l|l|l|l|l|l|l|}
\hline Week & Group 1 & Group 2 & Group 3 & Control & Mean & Prob. \\
\hline First week & $310.00 \pm 28.50$ & $317.00 \pm 31.23$ & $280.00 \pm 32.59$ & $305.00 \pm 32.59$ & 301.1 & 0.3394 \\
\hline Second week & $412.50 \pm 32.27$ & $425.00 \pm 25.00$ & $362.50 \pm 32.27$ & $406.25 \pm 51.54$ & 400.00 & 0.1781 \\
\hline Third week & $550.00 \pm 20.41$ & $550.00 \pm 25.00$ & $450.00 \pm 20.41$ & $575.00 \pm 54.01$ & 530.00 & 0.0014 \\
\hline Fourth week & $643.75 \pm 31.46$ & $650.00 \pm 25.00$ & $550.00 \pm 20.41$ & $693.75 \pm 37.50$ & 633.33 & 0.0002 \\
\hline Fifth week & $725.00 \pm 35.36$ & $733.33 \pm 38.19$ & $650.00 \pm 20.41$ & $815.00 \pm 37.75$ & 676.00 & 0.8391 \\
\hline Sixth week & $826.25 \pm 33.01$ & $891.67 \pm 38.19$ & $717.50 \pm 23.63$ & $916.67 \pm 38.19$ & 795.00 & 0.5255 \\
\hline Seventh week & $900.00 \pm 20.41$ & $1033.33 \pm 20.41$ & $812.50 \pm 32.27$ & $1116.67 \pm 104.08$ & 950.00 & 0.0001 \\
\hline Eighth week & $1000.00 \pm 40.82$ & $1150.00 \pm 50.00$ & $950.00 \pm 40.82$ & $1233.33 \pm 76.38$ & 1067.00 & 0.0001 \\
\hline
\end{tabular}

Table 2. Variation in mean weight of the broilers and net weight loss after slaughtering and removal of feathers

\begin{tabular}{|l|l|l|l|l|l|l|l|}
\hline Group & Group1 & Group 2 & Group3 & Control & Mean & Prob. & LSD $_{0.05}$ \\
\hline Weight of Broilers & $1016.67 \pm 28.87^{\mathrm{b}}$ & $1200.00 \pm 50.00^{\mathrm{a}}$ & $966.67 \pm 76.38^{\mathrm{b}}$ & $1233.33 \pm 76.38^{\mathrm{a}}$ & 1104.10 & 0.0015 & 115.30 \\
\hline Net weight loss & $150.00 \pm 0.00^{\mathrm{a}}$ & $116.67 \pm 28.87^{\mathrm{a}}$ & $133.33 \pm 28.87^{\mathrm{a}}$ & $141.67 \pm 14.43^{\mathrm{a}}$ & 135.42 & 0.3406 & 40.77 \\
\hline
\end{tabular}

*Means followed with the same letter in each column are not significantly different.

Table 3. Variation in weight gain of some organs of the broilers after preservation at $4^{0} \mathrm{C}$ for 24 hours

\begin{tabular}{|l|l|l|l|l|l|l|}
\hline Organ & Group1 & Group2 & Group3 & Group4 & LSD $_{0.05}$ & Mean \\
\hline Heart & $4.00 \pm 1.00^{\mathrm{a}}$ & $5.00 \pm 1.00^{\mathrm{a}}$ & $3.00 \pm 1.00^{\mathrm{b}}$ & $5.00 \pm 1.00^{\mathrm{a}}$ & 1.87 & 4.25 \\
\hline Head & $15.00 \pm 1.00^{\mathrm{ba}}$ & $20.00 \pm 1.00^{\mathrm{a}}$ & $13.00 \pm 1.00^{\mathrm{b}}$ & $25.00 \pm 1.00^{\mathrm{a}}$ & 5.17 & 18.25 \\
\hline Gizzard & $20.0 \pm 2.00^{\mathrm{b}}$ & $20.00 \pm 2.00^{\mathrm{b}}$ & $15.00 \pm 0.00^{\mathrm{c}}$ & $30.00 \pm 2.00^{\mathrm{a}}$ & 2.74 & 21.25 \\
\hline Leg & $15.00 \pm 0.00^{\mathrm{b}}$ & $20.00 \pm 2.00^{\mathrm{a}}$ & $15.00 \pm 1.00^{\mathrm{b}}$ & $20.00 \pm 1.00^{\mathrm{a}}$ & 1.87 & 17.25 \\
\hline Liver & $5.00 \pm 1.00^{\mathrm{b}}$ & $5.00 \pm 0.00^{\mathrm{a}}$ & $5.00 \pm 0.00^{\mathrm{b}}$ & $10.00 \pm 0.00^{\mathrm{a}}$ & 2.50 & 7.00 \\
\hline
\end{tabular}

*Means followed with the same letter in each column are not significantly different.

Table 4. The mean cooking loss and drip loss of breast meat sample of the broilers after cooking in hot water at $75^{\circ} \mathrm{C}$ for 30 minutes.

\begin{tabular}{|l|l|l|l|l|l|l|l|}
\hline Group & Group 1 & Group2 & Group3 & Control & Mean & Prob. & LSD $_{0.05}$ \\
\hline Cooking loss & $50.00 \pm 5.00^{\mathrm{a}}$ & $50.00 \pm 5.00^{\mathrm{a}}$ & $46.67 \pm 7.64^{\mathrm{a}}$ & $50.00 \pm 5.00^{\mathrm{a}}$ & 49.17 & 0.859 & 10.87 \\
\hline Drip loss & $20.00 \pm 2.00^{\text {ba }}$ & $25.00 \pm 0.00^{\mathrm{a}}$ & $15.00 \pm 3.00^{\mathrm{b}}$ & $25.00 \pm 5.00^{\mathrm{a}}$ & 21.25 & 0.012 & 5.80 \\
\hline
\end{tabular}

*Means followed with the same letter in each column are not significantly different.

\section{References}

Acamovie, T. (2001). Commercial application of enzyme technology for poultry production. World's Poultry Science Journal, 57, 225-242.

Del Carmen, J., Gernat, A. G., Myhrman, R. \& Carew, L. B. (1999). Evaluation of raw and heated velvet beans (Mucuna pruriens) as feed ingredients for broilers. Poultry Science, 78, 866-872.

Egbo, M. L., Doma, U. D. \& Lacdaks, A. B. (2000). Characteristics of small scale rabbit 
production and management in Bauchi Metropolis. Proceedings of the $26^{\text {th }}$ Annual Conference of Nigerian Society for Animal Production, Ahmadu Bello University Zaria, 1, 160-162.

Dahouda, M., Toleba, S. S., Youssa, A. K., Mana Ali, A. A. \& Hornick, J. C. (2009). The effects of raw and processed Mucuna pruriens seed based diets on the growth parameters and meat characteristics of Benin local guinea fowl. International Journal of Poultry Science, 8, 882-889.

Ekpechi, O. L. (1967). Pathogenesis of endemic goiter in Eastern Nigeria. British Journal of Nutrition, 21, $537-541$

Enwere, J.N. (1998). Foods of Plant Origin. Afro. Orbis Publication, Nssukka, Nigeria.

Esonu, B.O. (1996). Studies on methods of improving the nutritive value of jackbean (C. ensiformis) for poultry industry. Ph..D. thesis, Federal University of Technology Owerri, Nigeria. 66-69.

Ferriera, H. A., Pena, B. K., Gernat, A. G., Carew, L. B. \& Mutanoros, L. A. (2003). Evaluation of different processing methods of velvet beans (Mucuna pruriens) for use as feed ingredients for broilers. Tropical and Sub-tropical Agro-ecosystem, 8, 277-286.

Ihedioha, C.N. \& Okoye, C.O.B. (2011). Nutritional Evaluation of Mucuna flagellipes leaves: An Underutilized Legume in Eastern Nigeria. American Journal of Plant Nutrition and Fertilization Technology, 1, 55-63.

Makkar, H. P. S. \& Becker, K. (1997). Nutrient and anti-quality factors in different morphological parts of the Moringa oleifere tree. Cambridge Journal of Agricultural Science, 128, 311-322.

Olomu, J.M. (1979). Poultry Production in Nigeria: Proceedings of the first National Seminar on Poultry. A Publication of Ahmadu Bello University, Zaria. 20-32.

Omojola, A.B. \& Adesehinwa, A. K. (2007). Performance and Carcass characteristics of broiler chickens fed diets supplemented with graded levels of Roaxazyme G(R). International Journal of Poultry Science, 6, 335-339.

Rallof, F.S. \& Janet, G. H. (2003). Food for thought: Global Food trends. Science Newsonline.

Siddhuraju, P., Becker, K., Harinder, P., \& Makkar, S. (2000). Studies on the nutritional composition and anti-nutritional factors of three different germplasm seed materials of an underutilized tropical legume (Mucuna pruriens and utilis). Journal of Agriculture and Food Chemistry, 48, 6048-6060.

Tuleun, C. D. \& Igba, F. (2008). Growth and Carcass characteristics of broiler chickens fed water soaked and cooked velvet bean (Mucuna flagellipes). African Journal of Biotechnology, 7, 2676-2681.

Tuleun, C. D., Carew, S. N. \& Patrick, J. A. (2008). Fruit characteristics and chemical compositionof some varieties of velvet beans (Mucuna spp) found in Benue State of Nigeria. 
Livestock Research for Rural Development, 20, 10.

\section{Copyright Disclaimer}

Copyright reserved by the author(s).

This article is an open-access article distributed under the terms and conditions of the Creative Commons Attribution license (http://creativecommons.org/licenses/by/3.0/). 